\title{
Atmospheric Release Assessment Program (ARAP) Science and Technology Base Development
}

\author{
D.L. Ermak, G. Sugiyama, J.S. Nasstrom
}

\section{May 10, 2002}

Lawrence

Livermore

National

Laboratory 


\section{DISCLAIMER}

This document was prepared as an account of work sponsored by an agency of the United States Government. Neither the United States Government nor the University of California nor any of their employees, makes any warranty, express or implied, or assumes any legal liability or responsibility for the accuracy, completeness, or usefulness of any information, apparatus, product, or process disclosed, or represents that its use would not infringe privately owned rights. Reference herein to any specific commercial product, process, or service by trade name, trademark, manufacturer, or otherwise, does not necessarily constitute or imply its endorsement, recommendation, or favoring by the United States Government or the University of California. The views and opinions of authors expressed herein do not necessarily state or reflect those of the United States Government or the University of California, and shall not be used for advertising or product endorsement purposes.

This work was performed under the auspices of the U.S. Department of Energy by the University of California, Lawrence Livermore National Laboratory under Contract No. W-7405-Eng-48.

This report has been reproduced directly from the best available copy.

Available electronically at http://www.doe.gov/bridge

Available for a processing fee to U.S. Department of Energy and its contractors in paper from

U.S. Department of Energy

Office of Scientific and Technical Information

P.O. Box 62

Oak Ridge, TN 37831-0062

Telephone: (865) 576-8401

Facsimile: (865) 576-5728

E-mail: reports@adonis.osti.gov

Available for the sale to the public from

U.S. Department of Commerce

National Technical Information Service

5285 Port Royal Road

Springfield, VA 22161

Telephone: (800) 553-6847

Facsimile: (703) 605-6900

E-mail: orders@ntis.fedworld.gov

Online ordering: http://www.ntis.gov/ordering.htm

OR

Lawrence Livermore National Laboratory

Technical Information Department's Digital Library

http://www.llnl.gov/tid/Library.html 


\title{
Atmospheric Release Assessment Program (ARAP) Science and Technology Base Development
}

\author{
Donald L. Ermak, Gayle Sugiyama, and John S. Nasstrom \\ Atmospheric Science Division
}

\begin{abstract}
ARAP s integrated suite of research, development, and operational programs is focused on the creation of capabilities for predicting the consequences of atmospheric releases of hazardous materials. The foundation of ARAP lies in its science and technology base in multi-scale meteorological and dispersion modeling, field experiments, and software systems (databases, real-time data acquisition software, and remote-access tools). Scientific and technological advancements are integrated into DOE/NNSA s operational National Atmospheric Release Advisory Center (NARAC) at LLNL to support emergency response, pre-event planning, preparedness, and consequence analysis. Some recent ARAP development highlights are described below.

Urban Field Experiments. DOE/NNSA's Chemical and Biological National Security Program (CBNP) supported the multi-institutional URBAN 2000 dispersion field experiment conducted in Salt Lake City in October, 2000. Data from this experiment have been collected and archived on a LLNL web site (http://urban.llnl.gov) for distribution to participants. For the nocturnal conditions of this study, meteorological and dispersion complexity have been shown to result from the strong interaction of mesoscale flows with the urban area. Planning is currently underway for a second CBNP field experiment to study day-time convective conditions in Oklahoma City during the summer of 2003.
\end{abstract}

Urban Models. ARAP has developed a suite of models to simulate the effect of urban areas on atmospheric flow and dispersion:

- an urban parameterized version of the ADAPT diagnostic model, based on modification of the winds and turbulence in the urban roughness sublayer (coupled to the LODI dispersion model),

- an urban canopy version of the COAMPS weather forecast model, which incorporates drag, turbulent production, anthropogenic and rooftop heating, and modifications to the radiation balance, and

- a computational fluid dynamics model FEM3MP which explicitly resolves buildings.

The urban models are being evaluated against data from DOE s URBAN 2000 field experiment. The ADAPT/LODI urban parameterization yields statistical improvement over non-urban simulations. The COAMPS urban canopy model also dramatically improves wind and LODI plume predictions, and captures important wind directional shifts. Sensitivity studies are being conducted to determine the effects of model resolution, land-use, and urban model inputs. Improvements are needed to capture the exact timing of wind shifts and the lingering of the plume in the urban area. FEM3MP building scale model calculations show good agreement with the near-source tracer data. The sensitivity of FEM3MP results to inflow conditions and turbulence models is being analyzed.

LDRD Projects. ARAP currently has support for four LDRD projects to develop:

- Precipitation scavenging models coupled to NEXRAD precipitation data, with evaluation against detailed data available from the Atmospheric Radiation Measurement Program

- A multi-scale modeling system for integrated global-, regional-, urban-, and building-scale meteorological and dispersion simulations 
- A prototype sensor-driven modeling system for determining source characteristics and optimizing plume predictions, based on a methodology which combines Bayesian statistical comparisons and an efficient Monte Carlo sampling technique

- Integration of chemistry models into atmospheric transport and fate simulations

Atmospheric Radiation Measurement (ARM) Inter-comparison Study. ARAP staff led an international model inter-comparison effort to evaluate convective cumulus parameterizations used in climate models. The study made use of data from the DOE ARM Program and identified critical features of the parameterizations, such as triggering mechanisms. Improvements in such features will lead to more accurate simulation of convective process and associated clouds in climate models.

NARAC Remote-Access Technologies. NARAC is developing and deploying a suite of Internet and Web tools, which provide access to combined deployable rapid-response and reach-back central-system modeling capabilities. Three remote-access capabilities are being provided:

- the NARAC iClient, a Java software tool that permits users to enter release information and request and receive automated detailed predictions from NARAC s state-of-the-science meteorological and dispersion modeling system at LLNL,

- the NARAC Web Product Distribution system, which distributes NARAC products to multiple authorized users through a password-controlled Web page, and

- a new NARAC Web capability to provide a simplified Web-based interface for NARAC simulation requests (new development effort).

Homeland Security Support. Pilot projects are underway in Seattle and Albuquerque to develop approaches for integrating NARAC capabilities with local emergency management and response centers. NARAC is also engaged in a collaboration to couple Argonne National Laboratory s CBEMIS subway modeling system for the Washington DC Metro system with NARAC models.

NARAC Operational Support. NARAC was extensively used for DOE/DoD threat-response support during the heightened alert following the events of September 11, 2001. Simulations were also performed during the decontamination of the Hart Senate Office Building in January, 2002. NARAC deployments supported the Presidential State-of-the-Union Address (January, 2002) and the Salt Lake City Winter Olympics (January-February, 2002).

This work was performed under the auspices of the U.S. Department of Energy by the University of California, Lawrence Livermore National Laboratory under contract No. W-7405-Eng-48.

\section{Recent ARAP Publications}

- Bowen B M, R J Calhoun, J Rasanen (2002): Ceilometer Boundary Layer Measurements During the DOE VTMX/URBAN Field Experiment in Salt Lake City, AMS Fourth Symposium on the Urban Environment, Norfolk VA 2002 May 20-24. UCRL-JC-146138ABS.

- Bradley M M, M J Leach, C R Molenkamp, C H Hall, L A Wilder and L A Neher (2001): A National Wildfire Behavior Prediction Initiative: Full-Physics Models on Supercomputers, California's Wildfire Conference 2001: 10 Years After the 1991 East Bay Hills Fire, Oakland, CA, 2001 October 10-12.UCRL-JC-147051-ABS.

- Cederwall R T (2002): Large-Eddy Simulation of the Evolving Stable Boundary Layer over Flat Terrain. [Dissertation]. 
- Cederwall R T and R L Street (2002): Investigation of Episodic Enhancement of Turbulence in the Stable Boundary Layer Using Large-Eddy Simulation, AMS $15^{\text {th }}$ Symposium on Boundary Layers and Turbulence, 2002 July 15-19, Wageninge, The Netherlands.

- Cederwall R T, R L Street (2002): Episodic Turbulence in the Stable Boundary Layer Investigated with Large-Eddy Simulation, GEWEX ABL Study (GABLS) Workshop, 2002 March 25-27, Reading UK.

- Cederwall, R. T. and R. L. Street (2002): Heat Fluxes and Eddy Diffusivities from LargeEddy Simulation of Turbulent Episodes in the Stable Boundary Layer, AMS 12th Joint Conference on the Applications of Air Pollution Meteorology, 2002 May 20-24, Norfolk VA. LLNL Report No. UCRL-JC-146431-ABS.

- Chan S T, D E Stevens and P M Gresho (2001): Simulation of Natural Convenction Flow in a Cavity Using Finite Element and Implicit Projection Methods, First M.I.T. Conference on Computational Fluid and Solid Mechanics, MIT, Cambridge MA, 2001 June 14. UCRL-JC143054-ABS.

- Chan S T, D E Stevens and W S Smith (2001): Validation of Two CFD Urban Dispersion Models Using High Resolution Wind Tunnel Data, Third International Symposium on Environmental Hydraulics, Arizona State University, 2001 Dec 5-8. UCRL-JC-142234-ABS.

- Chan, S T, R. L. Lee and J. H. Shinn (2002): Large-Eddy Simulation Of Turbulent Flow And Diffusion Above And Within Forest Canopies, AMS 25 Conference on Agricultural and Forest Meteorology, Norfolk VA, 2002 May 20-24. UCRL-JC-146044-ABS-Rev. 1.

- Chin H-N S, M J Leach, J M Leone, Jr., G Sugiyama and H Walker (2002): Urban Effects in Numerical Models and Evaluation with Field Experiment Data: Part II: Mesoscale Aspects, Fourth Symposium on the Urban Environment, Norfolk VA, 2002 May 20-24, 2002. UCRLJC-146166-Abs-Pt2.

- Chin H-N S, M Leach, G Sugiyama and F Aluzzi (2001): A Preliminary Study Of Surface Temperature Cold Bias In COAMPS. Ninth Conference on Mesoscale Processes, Ft. Lauderdale, Florida, 2001 July 30-August 2. UCRL-JC-132216.

- Ermak D L (2001): Overview: Modeling and Prediction, DOE 2001 Chemical and Biological National Security Program (CBNP) Summer Meeting, Arlington VA, 2001 July 24-26. UCRL-JC-144561-ABS

- Ermak D L, and J S Nasstrom (2002): Atmospheric Dispersion Science for Emergency Response. UCRL-MI-146950 [Poster]

- Ermak D L, J S Nasstrom, J E Tull, R L Baskett, R Mosley-Rovi (2002): Local Integration of the National Atmospheric Release Advisory Center with Cities (LINC). Public Technology, Inc. Annual Conference Local Governments: Secure and On the Go, 2002 April 11-13, Scottsdale Arizona. UCRL-JC-147789.

- Foster K T, G Sugiyama and J S Nasstrom (2001): LLNL's Chemical and Biological Source Term Dispersion Modeling Data Base for the CBNP M\&P Thrust. UCRL-ID-143281.

- Gouveia, F. J. and J. H. Shinn (2001): Dense Network of Near-Field Observations of Building-Canopy Winds and Tracer Concentrations During the URBAN 2000 Experiment. Fourth Symposium on the Urban Environment, Norfolk VA, 2002 May 20-24UCRL-JC146206-ABS.

- Heagy, J., S. Warner, N. Platt, D. Larson, G. Sugiyama, J. Nasstrom, K. Foster, G. 
Bieberbach, and S. Bradley (2001): Controlled Comparison of HPAC and NARAC, Fifth George Mason University Transport and Dispersion Modeling Workshop, Fairfax, VA, UCRL-JC-144244-ABS

- Holt, T. R., H.-N. S. Chin, M. Leach, and G. Sugiyama, (2002): Sensitivity of Mesoscale Real-Data Simulations to an Urban Canopy Parameterization Fourth Symposium on the Urban Environment, Norfolk VA, 2002 May 20-24, American Meteorological Society, Boston, MA.

- Leach M J, H-N Chin and M J Brown (2001): Validation of an Urban Parameterization in a Mesoscale Model, Third International Symposium on Environmental Hydraulics, Tempe, Arizona, 2001 December 5-7. UCRL-JC-144677.

- Leach M J, H-N S Chin, J M Leone, Jr. , G A Sugiyama and H Walker (2002): Urban Effects in Numerical Models and Evaluation with Field Experiments Data: Part III: Comparisons to Tracer Data, Fourth Symposium on the Urban Environment, Norfolk VA, 2002 May 20-24. UCRL-JC-146166-ABS.

- Leach M J, M J Brown, H-N Chin, J M Leone, Jr. and G Sugiyama (2001): Fast Response Urban Modeling and Urban Parameterization for Regional Scale Models. DOE 2001 Chemical and Biological National Security Program (CBNP) Summer Meeting, Arlington, VA, July 24-26, 2001, UCRL-JC-144471-ABS.

- Leach, M. J. and F. J. Gouveia (2002): Apparent Interaction of Urban and Mesoscale Circulation in Salt Lake City during URBAN 2000, Fourth Symposium on the Urban Environment, Norfolk VA, 2002 May 20-24. UCRL-JC-146167.

- Leach, M. J., H.-N. S. Chin, et al. (2001): Urban Effects in Numerical Models and Evaluation with Field Experiments Data: Part III: Comparisons to Tracer Data, Fourth Symposium on the Urban Environment, Norfolk, VA, 2002 May 20-24. UCRL-JC-146166-ABS-Pt3.

- Lee R L, M J Brown, R J Calhoun, S T Chan, J M Leone, Jr. and D E Stevens (2001): High Resolution Modeling of Flow and Dispersion from Building to Urban Scales, DOE 2001 Chemical and Biological National Security Program (CBNP), Arlington VA, 2001 July 24 -26. UCRL-JC-144470-Abs.

- Lee R L, R J Calhoun, S T Chan, J M Leone, Jr. and D E Stevens (2001): Modeling of Building Scale Flow and Dispersion, Third International Symposium on Environmental Hydraulics, Arizona State University, Tempe AZ, 2001 Dec 5-8. UCRL-JC-142235-ABS.

- Lee, R L LLNL, Livermore, CA; and T. Humphreys and S. T. Chan, (2002): High Resolution Modeling Of Atmospheric Releases Around Buildings, AMS 12th Joint Conference on the Applications of Air Pollution Meteorology, Norfolk VA, 2002 May 20-24

- Leone J M, Jr., H Walker, M J Leach, H-N S Chin and G Sugiyama (2002): Urban Effects in Numerical Models and Evaluation with Field Experiment Data: Part I. Sensitivity to Urban Characteristics, Fourth Symposium on the Urban Environment, Norfolk VA, 2002 May 2024. UCRL-JC-146166-Abs-Pt1.

- Loosmore, G. (2002): Resuspension Modeling for Real-Time Emergency Response, $A M S$ 12th Joint Conference on the Applications of Air Pollution Meteorology, Norfolk VA, 2002 May 20-24. UCRL-JC-146174-ABS.

- Mirin A A, G Sugiyama, S Chen, R M Hodur, T Holt and J M Schmidt (2001): Development and Performance of a Scalable Version of a Nonhydrostatic Atmospheric Model, DOD High 
Performance Computing Modernization Program Users Group Conference, Biloxi, MI, 2001 June 18-21. UCRL-JC-142797.

- Monache, L.D., Perry, K.D. and R.T. Cederwall (2002): Comparison Of Aerosol Properties Within And Above The ABL At The Arm Program's SGP Site AMS 12th Joint Conference on the Applications of Air Pollution Meteorology, Norfolk VA, 2002 May 20-24. UCRL-LR146711

- Shinn, J. H., R. J. Pletcher, et al. (2002): A Simplified Dispersion Experiment in a 12-m Forest, AMS $25^{\text {th }}$ Conference on Agricultural and Forest Meteorology, Norfolk VA, 2002 May 20-24. UCRL-JC-146207-ABS.

- Sugiyama G, J S Nasstrom and J E Tull (2001): CBNP M\&P Thrust Area CB-NARAC Operational Systems Integration, Chemical and Biological National Program (CBNP) Summer Meeting, Arlington VA, 2001 July 24-26. UCRL-JC-144462-ABS.

- Sugiyama G, R Calhoun, S Chin, M Leach, R L Lee, J M Leone, Jr. and J Shinn (2001): LLNL Urban Modeling, Fifth Annual George Mason University Transport and Dispersion Modeling Workshop, Fairfax, VA, 2001 July 18-19. UCRL-JC-144114-

- Sugiyama, G., J. S. Nasstrom, H.-N. S. Chin, K. Foster, J. Gash, M. J. Leach, J. M. Leone, Jr., D. Maddix, J. Tull, H. Walke (2002): Advancement of a Real-Time Atmospheric Dispersion Modeling System, AMS Twelfth Joint Conference on the Applications of Air Pollution Meteorology Norfolk VA, 2002 May 20-24. UCRL-JC-146205-ABS

- Warner S, J Heagy, N Platt, D Larson, G Sugiyama, J Nasstrom, K Foster, S Bradley and G Bieberbach (2001): Evaluation of Transport and Dispersion Models: An Initial Controlled Comparison of HPAC and NARAC Predictions. UCRL-JC-144276

- Warner S, N Platt, J Heagy, S Bradley, G Bieberbach, G Sugiyama, J Nasstrom, K Foster and D Larson (2001): User-Oriented Measures of Effectiveness for the Evaluation of Transport and Dispersion Models. UCRL-ID-142520.

- Warner, S., N. Platt, J. Heagy, S. Bradley, G. Bieberbach, G. Sugiyama, J. Nasstrom, K. Foster, D. Larson (2001): Model Intercomparison with User-Oriented Measures of Effectiveness, Fifth George Mason University Transport and Dispersion Modeling Workshop, Fairfax, VA, UCRL-JC-144243-ABS.

- Xie S, R T Cederwall, J Yio and K-M Xu (2001): Intercomparison and Evaluation of Cumulus Parameterizations under Summertime Midlatitude Continental Conditions, Eleventh Atmospheric Radiation Measurement (ARM) Science Team Meeting, 2001 March 12-16. UCRL-JC-142040 Rev. 1.

- Zhang M H, J L Lin, R T Cederwall, J J Yio and X C Xie (2001): Objective Analysis of ARM IOP Data: Method and Sensitivity. Monthly Weather Review, 129: 295-311

- Zhang M H, R T Cederwall, S C Xie and J J Yio (2001): Status of Variational Objective Analysis for ARM IOPs: Update and New Challenges, Tenth ARM Science Team Meeting, San Antonio, Texas, March 13-17, 2001, UCRL-JC-145146-ABS.

- Zhang M, S Xie, R T Cederwall and J J Yio (2001): Description of the ARM Operational Objective Analysis System. UCRL-JC-144003. 


\section{An Integrated Suite of Research, Development, and Operat onal Programs}
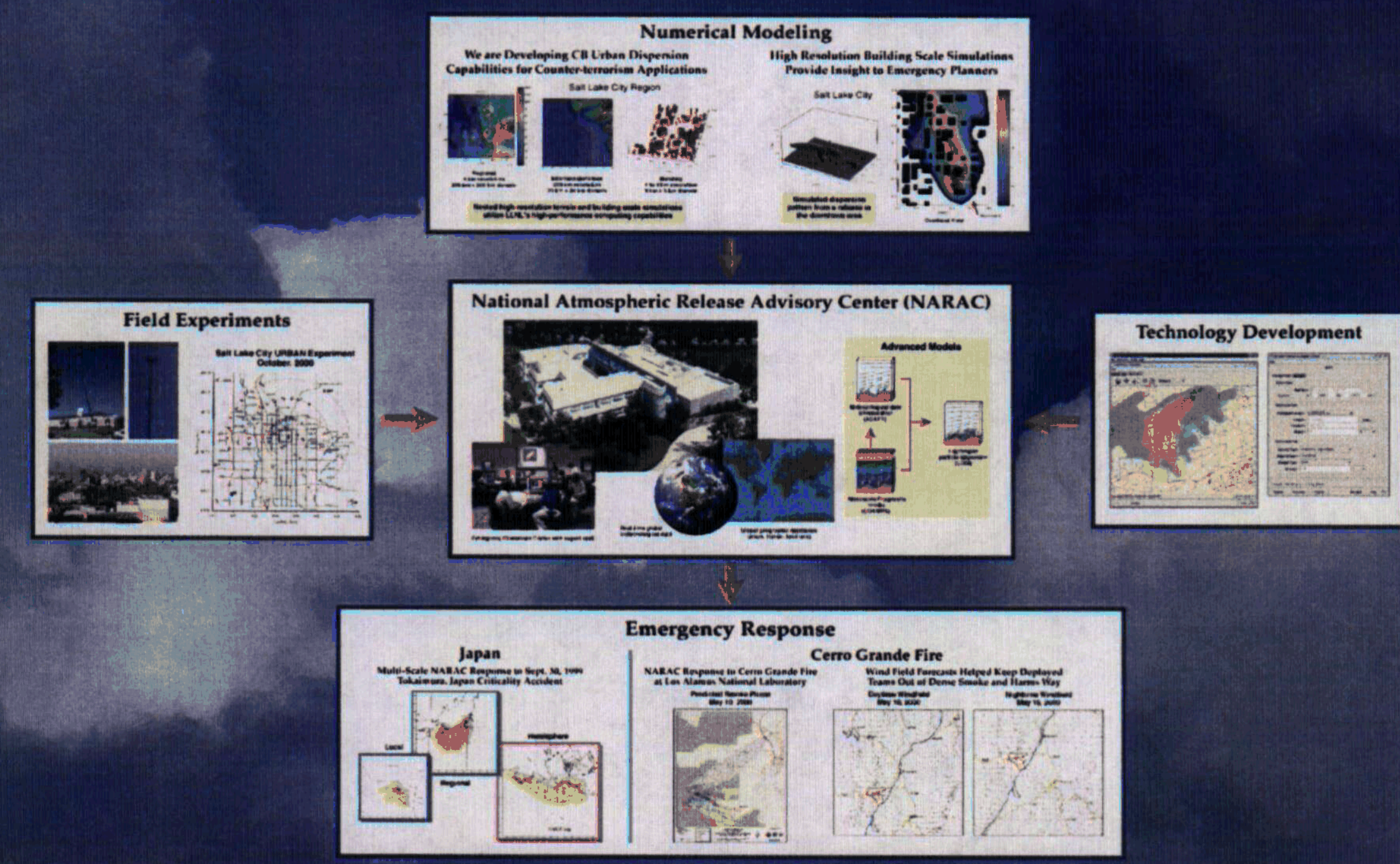

To Predict and Assess the Dispersal of Hazardous Material 